\title{
Pionini species (Hymenoptera, Ichneumonidae, Ctenopelmatinae) new to Finland
}

\author{
Reijo Jussila
}

Jussila, R. 2001: Pionini species (Hymenoptera, Ichneumonidae, Ctenopelmatinae) new to Finland. — Entomol. Fennica 12: 119-120.

The Pionini species (Ichneumonidae, Ctenopelmatinae) Lethades cingulator Hinz, L. curvispina (Thomson), Trematopygus helleni Hinz, T. rufator Hinz, Rhorus chrysopygus (Roman) and Rh. lapponicus (Roman) have been reported from Finland.

Reijo Jussila, Zoological Museum, Centre for Biodiversity, University of Turku,FIN-20014 Turku,Finland; E-mail: reijo.jussila@utu.fi

Received 7 March 1999, accepted 29 December 2000

\section{Lethades cingulator Hinz, 1976}

Lethades cingulator Hinz 1976: 101, O; 1996: 273, 우.

1 O has been found in V: Sauvo, Karuna 669:25 15.VI.1969 (R. Jussila leg.). This species has earlier been found in Poland, Germany, Austria, Scotland, Ireland, Turkey and Korea (Hinz 1996).

Lethades cingulator differs from the other Finnish Lethades species having rather dense puncture on the smooth and lustrous mesopleurons, distinct costulae of the propodeum, a yellowish clypeus and a black metasoma (Hinz 1976).

\section{Lethades curvispina (Thomson, 1883)}

Trematopygus curvispina Thomson 1883: 930, o; Brischke 1878: 91, 0’ㅇ․

Lethades curvispina, Aubert 1984: 56.

$10^{7}$ and 5 OQ have been found in V: Sauvo, Karuna 669:25 1962-69 (18.V.-5.VI.) and 1 \% in Turku, Ruissalo 671:23 25.V.1976 (R. Jussila leg.), and 1 ㅇ in Lohja 12.V.1959 (T. Kontuniemi leg.), 1 우 in EH: Forssa 5.VI.1965 (E. Nylund leg.), 1 \& in
EP: Vaasa 700:22 2.VI.1956 (Jussila leg.), 1 \& in Ks: Kuusamo 735:58 2.VII.1998 (Jussila leg.), and 1 우 in InL: Utsjoki, Kevo 774:50 3-9.VII.1981 (S. Koponen \& E. T. Linnaluoto leg.). Lethades curvispina has earlier been found from North Europe to Scotland, the Netherlands, the Alps and Russia up to Kamchatka (Hinz 1996).

Lethades curvispina most resembles $L$. scabriculus (Thomson, 1883) but its flagellae consist of 27-28 rather long and thin segments (scabriculus has 23-25 still more thinner segments) and its 1st tergite is 1.1-1.3× longer than broad (in scabriculus the ratio is $1: 1$ ).

\section{Trematopygus helleni Hinz, 1982}

Trematopygus helleni Hinz 1982: 25, ơ․․

1 O has been found in KiL: Kolari, Äkäslompolo 750:37 1.VII.1997 (R. Jussila leg.), and 1 O in InL: Utsjoki, Kevo 13.VII.1959 (Jussila leg.). This species has earlier been recorded only from Swedish Lapland and Russia, PsL: Petsamo (Hinz 1982).

In Trematopygus helleni the mesopleurons are lustrous but densely punctured; the clypeus is orange and the tegulae whitish (Hinz 1982). 


\section{Trematopygus rufator Hinz, 1985}

\section{Trematopygus rufator Hinz 1985: 272, ․}

1 h has been found in InL: Utsjoki, Kevo 30.VI.1956 (R. Jussila leg.). The species has also been recorded from Swedish Lapland, England and Germany (Hinz 1985).

From the Finnish species Trematopygus rufator most resembles T. vellicans (Gravenhorst, 1829) but its 1st tergite has no dorsal longitudinal carinae. It differs from $T$. helleni by its rough mesopleurons, black clypeus and dark tegulae (Hinz 1985).

\section{Rhorus lapponicus (Roman, 1909)}

Monoblastus lapponicus Roman 1909: 288, ర゚ధ. Rhorus lapponicus, Hellén 1937: 125.

$150^{7} 0^{7}$ and 13 우 have been found in EnL: Enontekiö 1905 (U. Saalas leg.), Malla (R. Frey leg.), and Kilpisjärvi 6.VII.1962, 5-11.VII. 1964 and 7-15.VII.1966 (V. Karvonen leg.). This species has earlier been found in Swedish and Russian Lapland, Ks: Salla (Roman 1909, Hellén 1937, Krogerus 1938), Czechoslovakia and United Kingdom (Yu 1999).

Rhorus lapponicus resembles Rh. substitutor (Thunberg, 1822) but its 1st tergite is distinctly (generally about $1.5 \times$ ) longer than its apical breadth, and the 1st and 2nd tergites lustrous (Aubert 1988).

\section{Rhorus chrysopygus (Roman, 1909)}

Monoblastus lapponicus var. chrysopyga Roman 1909: 290, .

Rhorus chrysopyga, Aubert 1988: 4, ơㅇ.

$1180^{7} 0^{7}$ and 134 우 have been reared from Dineura pullior Schmidt \& Walter (Hym., Tenthredinidae) (Schmidt \& Walter 1995) in InL: Utsjoki, Jesnnalvárri 766:49 22.VII.-25.VIII.1976 (L. Iso-Iivari leg.). In addition, $1 \mathrm{O}^{7}$ has been found in Utsjoki 769:47 8-17.VII.1981 (S.Koponen \&

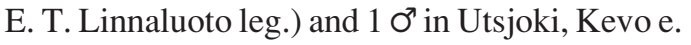

1. 1985 (S. Hanhimäki leg.). This species has earlier been recorded only from Swedish Lapland, Czechoslovakia and Southern Germany (Aubert 1988 and Yu 1999).

Rhorus chrysopygus greatly resembles $R h$. lapponicus (Roman, 1909) but its 1st tergite is as long as apically broad and its flagellae are shorter and thicker than they are in lapponicus. Its legs are wholly light; in lapponicus the coxae and hind femora are basally dark (Roman 1909, Aubert 1988).

\section{References}

Aubert, J.-F. 1984: Ichneumonides des collections suédoises et régles de nomenclature. - Bull. Soc. Entomol. Mulhouse 1984: 49-58.

Aubert, J.-F. 1988: Trosième prélude à une révision des Ichneumonides Scolobatinae: les Rhorus Foerst. du groupe de neustriae Schrk. - Bull. Soc. Entomol. Mulhouse 1988: 1-10.

Brischke, C. G. 1878: Die Ichneumoniden der Provinzen West- und Ostpreussen. - Schr. naturf. Ges. Danzig, N. F., 3. Heft: 35-117.

Hellén, W. 1937: Für die Fauna Finnlands neue Ichneumoniden (Hym.) IV. Tryphoninae. - Not. Entomol. 17: $123-130$.

Hinz, R. 1976: Zur Systematik und Ökologie der Ichneumoniden (Hymenoptera). — Deutsch. entomol. Zeitschr. 23: 99-105.

Hinz, R. 1982: Zwei Neue Arten der Gattung Trematopygus Holmgren (Hymenoptera, Ichneumonidae). — Nachr. Bayer. Entomol. 31: 24-26.

Hinz, R. 1985: Die paläarktischen Arten der Gattung Trematopygus Holmgren (Hymenoptera, Ichneumonidae). - Spixiana 8: 265-276.

Hinz, R. (†) (revised by Horstmann, K.) 1996: Übersicht über die europäischen Arten von Lethades Davis (Insecta Hymenoptera, Ichneumonidae, Ctenopelmatinae). - Spixiana 19: 271-279.

Krogerus, R. 1938: Parasitsteklar från torvmarkerna i Kuusamo-området. — Not. Entomol. 18: 105-108.

Roman, A. 1909: Ichneumoniden aus dem Sarekgebirge. - Natuwissenschaftliche Untersuchungen des Sarekgebirges in Schwedisch-Lappland 4: 199-374.

Schmidt, S. \& Walter, G. H. 1995: Description of Dineura pullior sp.n. (Hymenoptera: Tenthredinidae), with quantified observations on saw wear. - Entomol. Scand. 26: 385-392.

Thomson, C. G. 1883: Bidrag till kännedom om Skandinaviens tryphoner. - In Thomson, C. G. (ed.), Opuscula Entomologica 9(32): 387-936.

Yu, D. S. 1999: Interactive catalogue of World Ichneumonidae 1998: - CD-ROM, Taxapad, Bentall Centre, Vancouver, Canada. 